\title{
Los Reyes de Julio Cortázar: El Minotauro Redimido
}

El peronismo imperaba en la Argentina (1945-1955) cuando Cortázar publicó Los reyes (1948). ${ }^{ \pm}$Algunos críticos, en consecuencia, declaran que este drama minotáurico simboliza, veladamente, una condena a su país por aceptar este atavismo (eco lejano del rosismo) que se apoyaba en el "descamisado", actual representante del gaucho, ahora urba. nizado y proletario. ${ }^{2}$ Tanto en la Argentina peronista como en la Creta minosiana, la justicia estaba pervertida, se reverenciaban el poder heroico y las artes marciales, e imperaba un terrorismo que esclavizaba el cuerpo y el pensamiento. Además, habría cierto parentesco entre el porteño que se sentia aislado históricamente (terna dilecto de Mallea y otros argentinos) y el Minotauro en su laberinto, entre los intereses capitalistas ultramarinos que controlaban la economía argentina y el dominio militar de Creta sobre Atenas, y entre la lucha de "civilización y barbarie" con la que se entabla entre el Minotauro y Teseo. Estas y otras analogias pueden trazarse entre la realidad histórica argentina y Los reyes.

No obstante la oposición de Cortázar al peronismo, ${ }^{3}$ esta obra no pretende ser una sátira politica a la manera de Jonathan Swift, recubierta de un velo de clasicismo, mitologia y lenguaje elegante. La cosmovisión de Cortázar traspasa las fronteras nacionales y temporales y penetra ciertos enigmas que persiguen al hombre: el mal que acompaña al poder, sea individual o político, la cuestión axiológica del materialismo frente a la vida espiritual, la dualidad en el hombre entre su ser

1 Julio Cortázar, Los reyes (Buenos Aires: Gulab y Aldabahor, 1949). En el texto, entre paréntesis, cito de la $2^{\text {a }}$ ed., la de la Colección Indice, Edit. Sudzmericana, 1970.

2 Luis Bocaz cree que este drama se limita a un clandestino ataque a Perón: véase "Los reyos, o la irrespetuosidad ante lo real de Cortázar," en Aienea (Con. cepción, Chile), Año XLV, No. 419 (enero-marzo, 1968), pp. 47-55.

Sobre el peronismo $y$ el efecto que produjo en otro exilado, véase las declarationes de Entique Anderson Imbert, "Sesquicentenario", Sur, No, 267 (nov:die., 1960), pp. 35.38 . 
humano y animal. Relegando el posible vínculo con la Argentina a segundo término, exploraré desde una perspectiva literaria -enriquecida ésta por haber puesto en escena tal drama- las bases míticas y filosóficas, el alcance político, las imágenes y los móviles abiertos y ocultos de los personajes. Cortázar no presenta soluciones, sino problemas, tan anfractuosos como el laberinto mismo, y por eso un reflejo del hombre contemporáneo. Cortázar entronca con una larga y variada tradición -detallada en The Quest for Theseus - 4 que en poesia, drama, novela, revista, película y artes plásticas se ha interesado por las hazañas de Teseo. Conocedor de esta tradición, Cortázar se propone rehacer a su manera el mito cretense elaborado originalmente por Apolodoro, Plutarco y Ovidio. Vale notar, de pasada, que influyen en él, también, Góngora, Darío, Borges y Keats. ${ }^{5}$ Cortázar mismo, sin embargo, se desdobla en su propia fuente, puesto que en su obra posterior (Bestiario, Final del juego, Las armas secretas, Los premios, Rayuela), sigue elaborando temas y técnicas iniciadas en Los reyes. ${ }^{6}$ Conceptualiza una teratologia que permtie la porosidad entre el mundo de los animales y el de los hombres y entre el

1 Es un libro ilustrado con hermosas fotos de ánforas, estatuas, cuadros 7 frescos, y lo estructurä una colaboración de estudios inteligentes de Anne G. Ward, W. R. Connor, Ruth B. Edwatds, y Simon Tidworth (New York: Praeger, 1970). The Quest identifica (p. 37) el dibujo de la portada de Los reyes como un ánfora de figura negra de Vulci (actualmente en el Museo Británico).

Respecto a la tradición hispánica, The Quest analiza Fedra (1911) de Unamúno (pp. 235-236), y también nota que el secretario de Carlos V y Felipe II, Gonzalo Pérez, tradujo la Odisea, tomando por escudo personal el laberinto. (p. 209). Omite refertencias a Lope de Vega (Rimas sactas,, I, "Cuando me paro a contemplar. .."), a Borges, a Cortázar, y a Emilio Carballido. El dramaturgo mexicano me informó (nov. 1972) que él y Cortázar, durante una conversación, se sorprendieron de haber tratado un tema: afín: E. Carballido "Teseo: Tragi. comedia", en La Palabra y el Hombre (Revista de la Universidad Veracruzana), No. 24 (oct.-dic. 1962), pp. 651-673; y también en inglés, con un nuevo desenlace, en The Golden, Thread, trad. por Margaret Sayers Peden (Austin: University of Texas, 1970).

f Apenas hay cuento de Borges que no contenga un meandro intelectual, pero su representación física es más patente en "El jardín de senderos que se bifurcan," "La casa de Asterión,". "La muerte y la brújula," y "El inmortal." Respecto al romántico inglés, Graciela de Sola agrega: "Por Keats tiene Cortázar una confesada devoción. En los años en que escribió Los reyes seguramente se sintió identificado con el poeta de Endymion:" Véase Julio Cortizar y el bombre nuevo (Buenos Aires: Edit. Sụdamericana, 1968), pp. 135-136. Cortázar analizó "La urna griega en la poesía de Keats", en Revista de Ertudios Clásicos (Universidad de Cuyo, Mendoza, Argentina), Il (1946).

- Cito la opinión de Graciela de Sola en otro ensayo, "Ravuela: Una invitación al viaje". (en La vuelta a Cortazar en nueve ensajos [Buenos Aires: Carlos Pérez, Editor, 1969], p. 76): "Una íntima soldadura enlaza su último libro, Rayuela, con Los Reyes, publicado catorce años atrás, Sus temas y expresión se despliegan en un continuo avance $y$ enriquecimiento, sobre apuntamientos tempranamente establecido. La Ariadna herida de amor hacia el monstruo de belfos rumorosos" que asume su destino en Los reyes sobrevive, pues, bajo formas distintas, y aun podría sentirse su latido, no ya melancólico sino colmado en una simple y viviente "sagesse", en Ia Maga maravillada de Rayuela." 
"mundo de acá y allá," " la entropía y su función literaria, ${ }^{8}$ y el doppelgänger.

La inspiración más propincua e importante ha de ser la de André Gide, quien publicó su "Thésée" en Les Cahiers de la Pléiade (avril 1946).$^{\circ}$ A diferencia de la de Cortázar, la versión de Gide se adhiere a las leyendas recopiladas por Plutarco; ${ }^{10}$ Gide pinta a un Thésée heroico, astuto y trabajador, que equilibra la fuerza física con la inteligencia y la justicia. En estas y otras cuestiones de índole filosófica y estética Cortázar difiere de Gide, pero quisiera destacar tres similitudes: Gide, como Cortázar, considera que el proceso creativo tiende al auto-conocimiento: "Car il s'agit d'abord de bien comprendre qui l'on est" (p. 11). Segundo, los dos procuran revelar el mal que aqueja al hombre y a los dioses, pero Gide, en contraste, se empeña en que los dioses esclavizan a los hombres: "Tout paraissait divin, qui demeurait inexplicable, et la terreur s'épandait sur la religion, au point que l'héroïsme souvent semblait impie. Les premières et les plus importantes victoires que devait remporter l'homme, c'est sur les dieux" (p. 13). Ambos autores reflexionan sobre la muerte: Cortázar, joven, con brutal detención; Gide, viejo, puestos los guantes de terciopelo. Ambos convienen en que hay una dialéctica del poder, y que el impulso y la realización parricida

7 Graciela de Sola, Ibid,, pp. 78-79, sintetiza: "Esta predisposición a aceptar lo teratológico (Minotauro, figura clave de su obra), aunque reprimida luego por un sentido fuertemente realista, subyace en las páginas de Cortázar como una apelación hacia una realilad profunda y apenas entrevista, a la cual nos parece aplicables unas palabras de George Canguilheim: 'Se recurre a los monstruos para legitimár una visión intuitiva de la vida en la que el orden se desvanece frente a la fecundidad'. Pero ese orden que se desvanece es nuestro orden; si la ficción poética bucéa en el 'anti-cosmos' no es porque busque o se goce meramente en la abolición de un orden. Al menos en el caso de Cortázar, la abolición del orden se funde en la necesidad, por momentos angustiosa, de descubrir un orden, de conocerlo." El artículo de Canguilheim es el titulado "La monstruosidad y lo monstruoso," en Diógenes (Buenos Aires), No. 40. (diciembre, 1962).

8 Rudolf Arnheim discute esta cuestión en Entropy and Art: An Essay on Disorder and Order (Berkeley: University of California, Press, 1971), passim. En efecto, Cortázar ha intuido, sea en la estructura o en la temática de su obra, que la lucha constante universal es la que subsiste entre el caos y el orden, entre la disrupción de procesos lógicos organizados por el hombre, o este a sú vez creando sistemas ilógicos so pretexto de un razonamiento organizador superior.

"Las citas de "Thésée" son de Les Cabiers, aunque salió en libro aparte (Gallimard, juillet 1946). Cottázar, profesor de literatura francesa y partidario de la francofilia del grupo Sur, pudo leer el texto en francés, además de la traduc. ción de Sur, Nos. 147-149 (enero-marzo 1947), pp. 9-58, hecha por Patricio Canto, quien también reseñó "Thésée" en Sur, No. 150 (abril, 1947), pp. 77-80. Cortázar tradujo al castellano El inmondlista (Buenos Aires: Edit. Argos, 1947). Expreso mi sincero agradecimiento al Prof. Francis Carmody, de Berkeley, por sus consejos sobre Gide.

10 Consulté el cap. "Theseus", de Plutarcb's Gomplete Works; Parallel Liuss, I (New York: Wheeler, 1939). 
arrastran al hombre a construir $\mathrm{y}$ así construirse sobre las ruinas de sus antepasados.

\section{Acto 1}

Los reyes, en cinco escenas o actos breves, se desenvuelve delante y dentro del laberinto, punto de enlace entre tierra, mar y cielo, donde lo humano $\mathrm{y}$ lo divino confluyen para llevar a cabo una historia que determinará el destino de dos reinos (Creta y Atenas), y de cuatro protagonistas (Minos, su hija Ariana, el Minotauro y Teseo). Se observa fácilmente que el autor mantiene las unidades clásicas. Los reyes, sin embargo, se eleva sobre las reglas artificiales de la dramaturgia y adquiere mayor cohesión como un drama mítico realizado en un espacio sagrado - el laberinto transformando asimismo el tiempo y la acción en elementos sagrados. 11

La mitificación se percibe desde la escena inicial. Minos se queła a solas frente al laberinto anhelando la llegada de la barca anual, propiciatoria, cargada de las víctimas para el Minotauro, un acto cuyo significado sombrio resalta en la siguiente catacresis: "... vuelve cada año con una barca de llanto". El concepto personal que del tiempo posee Minos en espera del barco le imparte un sentimiento $\tan$ artificioso $y$ hermético que el tiempo se le escapa, se le para, como en la alusión barroca al caracol: "La nave llegará cuando las sombras, calcinadas de mediodia, finjan el caracol que se repliega para considerar húmedo $\mathrm{y}$ secreto, las imágenes de su ámbito en reposo" (11). El tiempo correspondiente a la llegada de la nave corre paralelo al que le hace falta al caracol para salir de su concha, múltiple comparación que irradia por la obra y abarca la lentitud (las imágenes estáticas), el silencio (mar, curva pared del laberinto), y la soledad esencial de los personajes. El caracol, en su inevitable $y$ lenta marcha, representa el sentido de justicia - de fatalidad que envuelve los actos de cada personaje, metáfora que podría extenderse a la misma inexorabilidad en el teatro griego. ${ }^{12}$

La coincidencia de tiempo secuencial y calendario, inmóviles y por tanto dotados de eternidad, con la repetición ("cada año") de un acto

11 Mircea Eliade, en Le Mythe de l'Eternel Retorr: Arcbétypes et Répétition (Paris: Gallimard, 1969), pp. 23, 30, 65, y passim, demuestra que la mente primitiva concibe el laberinto como un templo, un axis mundi, delante o dentro del cual se reúnen los fieles para repetir un acto sagrado. Por lo tanto, el lugar i sus atributos (tiempo, argumento y personajes), funcionan dentro de un marco mítico.

12 Puede haber cierto parentesco entre el caracol, viscoso e inútil, con la filosofía sartreana de la mala fe, tema expuesto en La Nausée. 


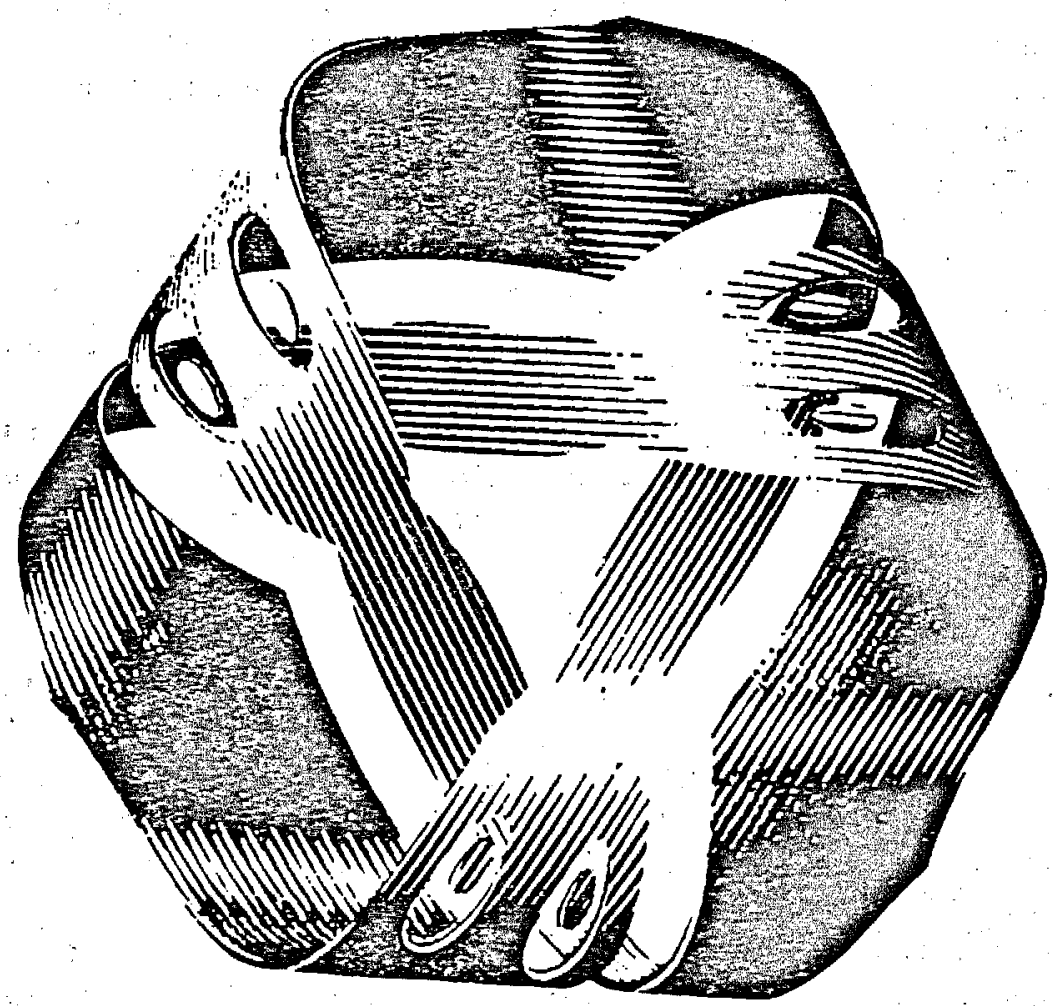

"Band VAN MöbiUs I" (Reproducido con permiso de la Vorpal . GALlery, de San Francisco, California). 
propiciatorio, presta a la temporalidad y al suceso una duración mítica. ${ }^{13}$ La validación de este aserto se revela en lo siguiente: En el momento indicado el autor prefiere la imprecisión de una "mañana" omnipresente, o mediodia de ese mismo día eterno, y pinta un "Sol ya alto y duro" para fijar la duración. Los eventos marchan, pero el tiempo y el espacio parecen no transformarse. También confluyen el tiempo y el espacio formando una unidad tal como la vemos representada en los grabados del holandés Maurits Escher, quien a su maneta, como Cortázar, juega con la topologia. Este aspecto es crucial para entender la obra entera, porque cuando la perspectiva espacial es trasladada al interior del laberinto, en la cuarta escena, no hay desarmonía o separación -ni en el sentido dramático ni en el mítico- puesto que exterioridad e interioridad implican una continuación emocional y dramática, análoga en la topología a la curva de Möbius, donde se rompe la distinción entre anverso $\mathrm{y}$ reverso (véase $\mathrm{l}_{a}$ ilustración que reproducimos). ${ }^{\text {14 }}$

Minos, tey del mar, duda de su capacidad de controlar las fuerzas temporales y divinas que cree se conjuran contra él. Sobre el plano de lo físico visible y de lo invisible onírico se urden tramas que exceden su comprensión: "iOh sueños en que ya no soy el señor!" (11). Su desintegración comenzó después de su inhabilidad de matar un hermoso toro, acto ordenado por Poseidón, dios del mar, para probar su lealtad y respeto. A consecuencia de este lapso sentimental, el iracundo Poseidón mandó que Dédalo construyera una vaca falsa y vacia en que se metió la hipnotizada esposa de Minos, Pasifae, para ser amada por el toro. Se desencadena, de ahí, una serie de sucesos que torturan al rey, siendo el mayor la construcción del laberinto para encarcelar a la prole de esa fornicación.

Minos se da cuenta de que el encarcelamiento físico del Minotauro sólo se debe a una imposición de su voluntad que en absoluto ha borrado su recuerdo o su presencia flageladora en los sueños. Minos se imagina "solo y desceñido" ante el Minotauro que se ha transformado en una figura cuya fuerza moral supera a la suya física. Minos, conquistador de tierras, mares y bienes, no puede vencer la intangible pesadilla persecutoria. Se imagina, por añadidura, que el Minotauro pueda destronarlo algún día: "¿No oyes? ¡Ese ruido! ¡Como si afilara su doble rayo

13 Plutarco da cada nueve años. Cierto deseo de verisimilitud le dictará a Cortázar un tributo anual. La tepetición coincide con lo dicho por Eliade, de que lo sagrado se basa en la renovación continua.

14 Véase "Moebius Strip I," en The Grapbic Work of M. C. Escber: Introduced and Explained by the Artist (New York: Ballantine, 1971), p. 41. Con el permiso de la Vorpal Gallery, San Francisce, California, reproduzco "Band
van Móbius I." 
contra el mármol!" (18). Desde que la bestia hubo estado en el palacio -tiempo pre-laberíntico- Minos sospechó que tramaba su derrota: "Fue preciso vestirlo de piedra para que no tronchara mi cetro" (19). Cuando el Minotauro corroe la relación entre padre e hija, el rey amenaza aptesarla en el laberinto si persiste en defender a su medio hermano. Minos utiliza su poder temporal con la esperanza, siempre vana, de dominar su ambiente sin comprender que la fuerza física se subordina a: una fuerza mayor y ajena a él.

Aun cuando Minos pudiera enfrentar de buena fe el acto traicionero, no solucionaría el dilema, porque no se trata simplemente de una purga psicoanalítica, sino de un conjuro de fuerzas divinas y de voluntades humanas que ni el poder real -benévolo o despótico- puede alcanzar. Se lanza ciegamente, pues, a una explicación inventada del ultraje, con el fin de justificar la muerte de Pasifae y para contrariar simultáneamente el amor de su hija por el hermano hombre y toro. Comienza negando que Atiana naciera de Pasifae: "Las madres no cuentan"; "Tú naces de mí como el aroma del vino profundo" (15). Le aplica otros epitetos que acentúan su prosapia paternal y su pureza: "Hija de rey, paloma de oro". De esta manera realza su idea fija que Ariana no fuera concebida por impulsos sexuales ilícitos, lo cual contrasta con el origen lascivo del Minotauro.

Minos procura apartarlos aún más repitiendo una descripción incriminante del raptó atribuida a Axto, ${ }^{15}$ compañero (quizá guardaespalda) de Pasifae. Este se resistió a la delación, hasta que "al tercer día de suplicios Axto derramó la verdad con la sangre". Es evidente que Minos inventa la "verdad" que coincide con un juicio preconcebido, como cuando la condena en términos personales y arbitrarios a una participación activa: "... estaba ya en la vaca luminosa, delfín de oro ${ }^{16}$ entre las hierbas, y fingia un mugido solitario y blando..." (16). Declara que Pasifae gozaba del acto sexual, pero se transparenta su propia relación con ella: "Al grito sucedió el gemir del goce, su lasciva melopea que en mi recuerdo se mezcla todavía con azafrạn y laureles." Minos pudo haber salvado a Pasifae de la muerte si no hubiera oido decir su última palabra humillante del moribundo Axto: "sonrisa."' Pas Pasifae

is No hallo este nombre en ningún diccionario; puede ser una invención del autor.

18 El delfín de oro está pintado en las paredes de la sala de trono del palacio de Crossos. Hay fotos del delfín en el artículo por Carlos Areán, "En el alba de Creta", La Estafeta Literatia (Madrid), 15 de agosto de 1971, pp. 4-9.

17 Acaso el motivo de la risa nazca del taurómaco . Henry de Montherlant, quién en su Pasipbá (Sceaux: Palimugte, 1947), pinta a una reina desafiadora de la moralidad existente. Aunque a ella le cueste la vida, se jacta de su amorío 
pagó por su gozo: "El ánfora ya rota en pedazos execrables" (15). En un arranque de soberbia y auto-absolución, caracterizadas por la objetivación y el menosprecio de Pasifae y de la hembra en general ("Las madres no cuentan". (14).), Minos descarta su propio fallo ante Poseidón. ${ }^{18}$

Mientras que el fantasma del Minotauro puebla los sueños de Minos, apresándolo, aminorando su libertad temporal, el tey lamenta, en una irónica inversión de papeles que recuerda a Segismundo, su pérdida de fuerza. Los sueños se hacen "tarea real" (19) para Minos, fiador de substancias: laberinto, hachas, muerte, destrucción. Es un materialista perseguido por sueños que adquieren proporciones verosímiles. Desea servirse del sueño mismo para aniquilar la pesadilla que lo inculpa, y para lograrlo, prefigura la posibilidad de que el Minotauro no sea feroz -o que no sufra por su encarcelamiento: "enorme y dulce, enorme y libre" (11).

Soberbio en medio de su dilema, Minos no quiere creer que sus sueños lo tiranicen, sobre todo delante de Ariana, más aterrorizada que él: "Una mujer no sabe mirar. Sólo ve sus sueños". Ariana parece alentarse por los sueños: "¿Quién lo tornó feroz? Tus sueños" (19). Ariana culpa a su padre de que el Minotauro lo espante. Minos aseguró apresarlo por feroz, pero Ariana declara que "era simple y callado". (18) lo cual implica que Minos inventó la ferocidad y la pesadilla: "El es tu obra furtiva, como la sombra del árbol es un resto de su nocturno espanto" (19). Ariana le asigna a Minos su propio laberinto: "Tú tienes el tuyo poblado de desoladas agonías" (20).

Ariana tampoco carece de sueños que pintan laberintos imaginarios: "Mi laberinto es clato y desolado, con un sol frío y jardines centrales donde pájaros sin voz sobrevuelan la imagen de mi hermano dormido junto a un plinto". Imagina a un Minotauro presente a base de una perspectiva antigua y borrosa, de cuando estaban en el palacio: "No me dejaban hablarle, pero a veces nos mirábamos distantes..." (18). Este Minotauro es "manso y sumido; dormía sobre el follaje seco". Busca esta imagen para refutar la que creó su padre, la de una bestia hambrienta y colérica que devora "a las vírgenes de trenzas claras". Pero Minos no la deja tranquila y niega el sueño de que el Minotauro no

y de su fidelidad a su propio modo de ser: ".....je meurs au milieur d'un tire immense" (p. 42).

18 Montherlant, Ibid., incluye en un "Apéndice" un papiro suelto de un drama perdido de Euripides, Les Crétois. En el contexto de Los reyes, vale notar que en este pergamino Pasifae se declara inculpable, cargando la responsabilidad : Minos por haber enfurecido : a Poseidón ( $\mathrm{pp}$. 56-57). 
destroce a los jóvenes atenienses con el hecho irrefutable de que "los atenienses no volvieron a salir" (19).

En este punto Ariana contesta en varios niveles mostrando que sí "sabe mirar" y raciocinar. Rechaza la desolación del Minotauro simple. mente porque Minos ha tenido "desoladas agonías", y porque éste quiere infligir su agonía al Minotauro. Arrebata el pensamiento de Minos, materialista, quien a base de consecuencias procura adivinar las causas: Post boc ergo propter boc. Pone en tela de juicio el concepto lógico y epistemológico de aquel momento: "Nadie sabe qué mundo multiforme o qué multiplicada muerte llenan el laberinto". Su emoción le dicta, sin poder probarlo, la creencia de que los atenienses vivan. Sin embargo, la misma vacilación que siente en renunciar al mundo por amor a su hermano, ja lleva a dudar - ideando a la inversa de Minos- que el Minotauro manso del palacio no haya podido transformarse en la bestia del laberinto. Ella empieza a debatir el dilema: " $i$ Saber; sueño meridiano! ¡Acceder, confirmar! $Y$ en el borde mismo retrocedo como una ola sucia de arena, me repliego a mi confusa ignorancia donde bate la delicia del horror, la esperanza renovada!" (20).

Sin poder expresar abiertamente el amor a su hermano, Ariana reta a su padre por haberlos separado. No puede declarar abiertamente su amor profundo, peto todo su ser busca unirse con él. Esta lucha, individual y mutua entre los dos, interna a la vez que externa, suministra al drama su gran tensión. Su intranquilidad ante el dolor de su padre está compensada por el amor a su hermano, tensión que ella resume en estas palabras: "... siento correr una caliente savia de púrpura y limón por mi lengua lacerada" (17). Esta combinación de sangre y ácido indica una transposición de elementos gustativos (calor, sabor a sangre, herida, amargura) en elementos cromáticos que a su turno reflejan la división anímica de Ariana entre dos lealtades.

La preocupación de Ariana de perseguir su destino termina en un miedo enorme que la hace retroceder cuando está a punto de entrar en el laberinto. Ariana no puede reconciliar el mundo externo con-el de adentro: "Estamos de este lado de esas piedras. .. el muro del arquitecto segmenta nuestros mundos" (20). Al final, ella cae en un escepticismo que no la deja actuar ni reconocer su deber. Este escepticismo resulta en una victoria huera para Minos, que cree haberla convencido de la justicia de su acto: "Ahora eres la reina". Contesta ella: "Ahora no sé quién soy" (22).

Resaltan de inmediato las profundas dicotomías entre Minos y Ariana; ésta repudia la condena del Minotauro y el odio contra su madre, 
lo cual enfurece más al rey. Contra esa corriente de antagonismo filosófico, promotora de tensión dramática, fluye otra, sintáctico-metafórica, de una armonia entre sus respectivas hablas. Es notable el uso del símil en este procedimiento:

\section{Artana}

"Eres como una lámina de bronce." (13)

"Saber una cosa no es como escucharla." (15)

"Nos abriga de su imagen como un escudo." (15)

"... como los curvos ojos de marfil en las figurillas votivas." (18)

"Lo digo como si escupiera los huesecillos de una paloma asada." (19)

"... como la sombra del árbol." (19)

"... como la pared del pecho..." (20)

".. retrocedo como la ola sucia de arena..." (20)

\section{Minos}

"...como un golpe de ramas secas en la cara." (13)

"Tú naces de mí como el aroma del vino profundo." (15)

"... se les veía subir por la pradera como las barcas egipcias que traen a los emisarios y las vendas perfumadas." (15-16)

"El toro vino a ella como una llama que prende en los trigos." (16)

“ Ese ruido! ¡Como si afilara su doble rayo contra el mármol! (18):

"Vendrán vestidos de lágrimas como todos los años." (21)

La construcción bimembre corresponde a la dicótoma relación entre los dos; sin embargo, el empleo exclusivo del símil en el diálogo -que contrasta con la ausencia de esta figura retórica en sus respectivos monólogos- subraya el vaivén sicológico. Ariana y Minos emplean el símil19 para fines análogos: describir actos violentos, negar (Ariana) y afirmar (Minos) la prosapia común, referirse al impenetrable y temeroso laberinto, palpar lo intangible ("imagen", "aroma"). Este proce-

19 Consúltese "Simile", en The Encyclopedia of Poetry and Poetics, ed. Alex Preminger, 2a ed. (Princeton: Princeton University Press, 1965). 
dimiento resulta en un simil extendido e imaginativo en que Ariana, sin querer, se parece a su padre, $\mathrm{y}$ en que reciprocamente se acentúa el anhelo minosiano de que Ariana sea como él.

El esfuerzo continuo de Minos de subrayar su paternidad empuja a Ariana a una posición contraria, la de no fiarse sino en sí misma y en el Minotauro: "Hablar es hablarse" (12). Pero llega un momento en que los dos cesan sus respectivos monólogos aislados y se enlazan por la siguiente pregunta clave que abre paso al tema del "doble"20: "¿Tienes miedo del eco?" (13). De aquí en adelante, los dos buscan integrarse y separarse simultáneamente uno contra otra. Esto ocurre en el plano auditivo ("eco"), y también en el plano visual los dos se refuerzan al reflejarse cuando Ariana dice: "Eres como una lámina de bronce, me oigo mejor si te hablo. Cuando llegué tú te escuchabas en el alto espejo del aire". Es el triple eco del condenado Minotauro, de la solitaria Ariana y de la conciencia lacerada de Minos.

Se puede esquematizar cómo Minos y Ariana desencadenan dos series de conceptos e imágenes imbricadas. Consta en la primera serie, iniciada por Ariana, la manera en que Minos se sirve del léxico o del concepto de ella sólo para repudiarlos.

Minos

ARIANA

"Como en todo espejo, alguien que "... alto espejo del aire." (13) sabe y espera." (13)

"Un monstruo no tiene hermanos." "Es mi hermano." (13) (14)

"Las madres no cuentan."

"Tú eres la hija de un rey." (14)

"El ánfora ya rota en pedazos execrables." (15)

"Los dos nos modelamos en el seno de Pasifae." (14)

"Ella ha sido mi madre." (14)

"Nadie me libró de escucharlo." "Saber una cosa no es como escu(15) charla." (15)

A partir de la historia del rapto, Minos inicia las imágenes y lós pensamientos:

20 Sin mencionar Los reyes, Marta Morello-Frosch estudia "El personaje y es siempte, indefectiblemente, cómica. Toda ella suena en esa sola cuetda y tono. (1968), pp. 323-330. 
MINos

ARIANA

"El toro era del norte, rojo y hen- "El toro era del norte, rojo y henchido..." (17) chido." (17)

"Con palabras te lo diré para que "Lo digo como si escupiera los huela vomites de tu cotazón y seas so- secillos de una paloma asada, las lamente la hija del rey." (15) escamas del pescado." (17)

Anterior al rapto la seguridad política de Minos permanecía intacta, su honra íntegra, su auto-confianza imperturbable. El pasar revista a la seducción quebranta su emoción. La susodicha inversión de papeles destaca la ironia del desarrollo lingüistico-imaginario con respecto a la fuerza psíquico-política. Ariana imita el patrón lingüistico e ideológico de Minos, pero éste no controla definitivamente el ser de ella, lo cual es determinado por el Minotauro. La prueba de esto está en la exégesis de la previa alusión de Ariana: ella rechaza el epíteto que le aplicó su padre ("paloma de oro"), y desea transformarse en la "paloma asada", o muerta, que renuncia a su pasado aéreo ("[escupe] los huesecillos") y marítimo (Minos, rey del mar, "[escupe] las escamas del pescado").

\section{Acro II}

Los personajes son como frisos, con la salvedad de que monologan y dialogan, única modalidad de acción. Ni la llegada de los catorce atenienses —-sumisos a pesar de su potencial destrucción- ni la polémica acalorada entre Minos y Teseo, pueden turbar las condiciones estáticas ya notadas. Teseo refuerza la inmovilidad de Ariana, que pasó a segundo término para "quedar apoyada en la pared del laberinto", (25) con la alusión de que "Coincide su túnica "con... aquellas columnas" (28). Un "sol que cae a plomo" bajo un "cielo de un azul duro y ceñido" implica la detención del tiempo y del movimiento de los personajes. Es especialmente sugestiva la frase "Los condenados permanecen a distancia, mirando hacia el laberinto", (25) porque brinda una triple referencia de inmovilidad: "condenados" carecen de rumbo propio; "permanecen"; "mirando" desafía su sentido sintáctico y apunta a los ojos carentes de expresividad. Toda tendencia motora en los conflictos se estanca en un equilibrio de ceto, ora una resolución verbal, ora una resignada aceptación del destino, con dos notables excepciones: Teseo está encadenado a una dialćctica del heroísmo que no permite cansancio físico; el Minotauro, al ofrecerse a morir, como veremos; 
para la voz y el cuerpo, pero traspasa espiritualmente los muros de su prisión.

Resulta irónico que el que condena a los atenienses muestre $\longrightarrow$ pretenda mostrar - compasión; Teseo, en contraste, se niega al más leve sentimiento -aún consigo mismo- y se aleja de sus coterráneos con asco. Acepta instintivamente que sobrevivirá el que más se arriesgue, y too se dejará conducir al laberinto como un cordero al sactificio. Su heroísmo consiste en "sacar la espada" "sin preguntar mucho" el significado de su acto, ya que no está habilitado para el pensamiento: "yo iba al gimnasio y dejaba que mis maestros pensaran por mi" (37). Palabras y filosofías, según Teseo, no explican su condición de "héroe", y lo que le hace actuar es "un movimiento $y$ una fuerza" que le "vienen de la estirpe" (33). De esta manera él cumple en Cnossos con una misión que está en su sangre y continúa haciendo un papel que le concede validez ontológica.

Teseo y Minos se enfrentan en una contienda en que aquél rechaza arrogantemente cada esfuerzo de escarnio:

Minos: ¿Quién eres tú que me arroja su ácida flecha a tan pocos pasos de la muerte?

Teseo: Un igual.

Minos: Teseo. (27)

Minos, por fin valora la presencia majestuosa de Teseo, a la vez que éste confiesa implícitamente la estima a Minos, quien le servía de modelo en el uso del poder y la astucia. Esto no impide el que Minos amenace dos veces con la muerte a este joven intrépido que ha muerto (entre otros) al jabalí Crimoniano y al toro Maratón. Minos vislumbra, de pronto, que "Teseo el matador" podria servir en su plan, todavía amorfo, de eliminar al Minotauro. Minos está inseguro aún de si una álianza con Teseo no fuera a desembocar en una trampa y pone 2 prueba el valor de Teseo: " $\mathrm{O}$ h insensato, pasto codiciado del Minotauro!" (29). . Ante estas amenazas Teseo no retrocede, pues no ha venido a Cnossos a morir sino a derribar al monstruo. "No has venido a morir", (28) declarado confusamente por Minos, termina en la doble aserción dogmática de Teseo, "Tú ya sabes que no" $(29,30)$. En. el acto, Minos ve con mayor claridad su alianza con Teseo. Teseo y Minos se unen por un procedimiento que recuerda al que se utilizó en el primer acto, entre Minos y Ariana; asi se guarda la simetría entre y dentro de las escenas. La supuesta superación de diferencias entre los reyes es análoga a la superficial resolución entre padre e hija. 
Tèseo persigue cuatro metas en Cnossos, analizadas a continuación: 1) destruir al Minotauro de tal modo que todos reconozcan su heroísmo; 2) llevarse a Ariana; 3) destronar a Egeo para hacerse rey; 4) vengarse, por último, de Minos por haber impuesto el humillante tributo. Como todas las metas están entrelazadas, Teseo no puede prescindir de ningún paso si quiere realizar sus fines. El triunfo sobre el Minotauro implica, entonces, una satisfacción de orgullo y una conquista política. La crecida fama que busca al librat al mundo del "último monstruo", (41) sólo es asequible si puede escaparse para promulgar la victoria anticipada: "Si no vuelvo cómo sabrán en Atenas que he matado al Minotauro ilustre?" (31). "Ilustre", expresado con sorna, revela que Teseo reprocha a la bestia la atención cosechada, motivo más que suficiente para destruirlo. Al poder escaparse del laberinto, habrá logrado dos actos milagrosos (muerte y evasión); que a los ojos de los atenienses le concederá una imagen de invencibilidad.

Ariana se convierte en una metafórica nota promisoria que ha de redimir a ambos. Tan harto está Minos de sus deslealtades que no la echará de menos. Es más, la presencia de Ariana en Atenas como esposa y reina de Teseo garantizará la paz política: "Sólidos nuestros tronos" (42). Teseo se aprovechará de su presencia en la mejor oportunidad para subir al trono y conseguir la anulación del tributo - esto está sobreentendido ya que nunca menciona abandonarla en Naxos- lo cual rescata la honra de los atenienses y elimina el temor anual del sacrificio. Teseo aparenta aceptar la demanda de que calle el besticidio a cambio de Ariana, acto vacilante que, hasta este punto del drama, nos lleva a calificarlo de héroe burgués, el que vende su misión vital para calmar su inquietud sexual.

Plutarco describe a Teseo como un hijo ansioso de regresar para deleitar a su padre. Egeo, que le tiene intenso afecto, se lanza al mar, adolorido, al divisar la vela negra, izada erróneamente y emblema de la muerte de su hijo en el laberinto. En contraste, ningún cariño se insinúa en Los reyes, porque Teseo desprecia la vejez e impotencia de su padre, responsable del fracaso militar y político de su país. El Teseo de Plutarco, republicano y benévolo, contrasta marcadamente con el de Cortázar, dispuesto a restablecer un régimen totalitario: "Además soy rey. Egeo está ya muerto para mí. Atenas eicontrará pronto a su amo" (34). Por su parte, Minos descubre en este potencial usurpador y parricida a un aliado que, coronado, le será obediente por no querer ver derrocada otra vez su nación.

La alianza durará poco, puesto que, logrado lo antedicho, Teseo 
planeará la destrucción de Cnossos debido, ostensiblemente, al tributo cíclico y afrentoso. El que reprochaba la cobardía a los condenados y despreciaba a su padre, de pronto y con hipocresía, busca vengarse del que había infundido pavor a los atenienses y al rey caduco. Motiva a Teseo en esta cuestión la respuesta a la pregunta irónica: "¿Por qué renuevas el tributo?" Responde Minos con soberbia: "Hubieras hecho lo mismo en mi lugar. Egeo tiembla cuando los vientos empiezan a alzarse desde las aguas, y el plazo se cierra inevitable. Y luego la ceremonia, el pavor de Atenas" (38). Se evidencia aquí que ambos se guían del poder $\mathrm{y}$ de la astucia, y que ningún pacto es inviolable. Lo ejemplifica la demanda minosiana de que Teseo no promulgue la muerte del Minotauro, ya que podrá seguir hechizando a los propios cretenses con su poder sobre el mundo subterráneo e imponiendo el tributo a los atenienses. Teseo co-participa provisoriamente de esta duplicidad, porque quien solía vivir de proezas y jactancias no puede negar su patrón acostumbrado. Teseo, a su turno, violará su acuerdo al gritar su conquista y al servirse de Ariana como escudo ante las posibles represalias de Minos.

ACTO III

Ariana permanece a solas e inmóvil ante la entrada del laberinto, en su mano el ovillo decreciente que la une por Teseo al Minotauro. En su monólogo explica el sobreentendido acuerdo entre ella y Teseo a la vez que se imagina el recorrido sinuoso, el encuentro y luego las palabras intercambiadas entre Teseo y el Minotauro. Aunque ella ignora la condición de su hermano, ya no lo concibe como parte del pasado, y por tanto, inasequible, sino en un futuro de probable reunión ("será más rojo", "se enhiestarán", "paseará", "o hablará [49]), aspecto verbal que implica una reconciliación entre su deseo actual y la esperanza anhelada. Ella lo proyecta, también, fuera del tiempo histórico a un plano sideral, acto que conviene con su nombre, Asterión: "gusto por las nomenclaturas celestes y el catálogo de las hierbas".

Este audaz expediente por parte de Ariana de unirse con su pasado trunco está hecho racionalmente y con premeditación, sin el hechizo de Afrodita que impulsó a Pasifae. Ariana rehusa ser "hija del rey" y se lanza, voluntariamente, contra la tradición toda, para repetir lo de su madre: ". . ven a la hija de la reina, sedienta de tus belfos tumorosos!" (51). La separación física, sin embargo, se mantendrá siempre; el Minotauro, por su cuenta, se decidirá por no regresar jamás. 


\section{Acro IV}

Cortázar no se ocupa de la presunta tortuosa y tenebrosa búsqueda porque Teseo no va a perderse. El destino lo conduce a la meta tal como la premeditación (el hilo mágico) lo llevará de nuevo a Ariana y a la libertad. Consta que el hilo prueba la fidelidad de Ariana, pero ¿a quién? El no sospecha, $\tan$ confiado estaba, que ella lo vaya a traicionar, $y$ que la misma cuerda pueda ser el salvoconducto destinado a su adversario. Ariana le dijo a Teseo: "Si hablas con él dile que este hilo te lo ha dado Ariana'" (50). Palabras clave que simbolizan el amor de Ariana, pero como Teseo no las comprende, las transfiere a su estilo arrogante: "Me dio este hilo, para recobrarme cuando te haya matado" (59). En este punto el Minotauro empieza a desconfiar de Ariana, de su amor hacia ella, y de su relación con Teseo: "Ariana mezcló sus dedos con los tuyos para darte el hilo" (60). Se cree capaz de vencer a Teseo, pero la propia división física parece extenderse a una ambigüedad emocional y filosófica que atenúa su poder destructivo: "Ahora ol odio rojo monta por mi frente, sé que debería matarte, seguir la senda que el hilo me propone, alzarme hasta las puertas como un sol de espuma negra... ¿Para qué?... ¿Para quién? (61). Esta doble interrogación le hace concluir que no se redime en "la otra cárcel, ya definitiva, ya poblada horriblemente con su rostro y su peplo". El rostro, el de Ariana, y el peplo, el chal de las mujeres, no se refieren simplemente a una decisión estética de rechazar las formas superficiales de los humanos porque no corresponden - cabeza taurina y cuerpo humano desnudo- a la del Minotauro, sino que el Minotauro reclama contra su constante dicotomía ontológica.

El hilo es metaforizado por la fantasía del Minotauro en un arroyo, y luego en "viborilla de agua que señala hacia el mar", (59) símbolo de Ariana. Recuerda que los estanques del palacio reflejaron su condición de toro-hombre, estado que le condenó a la soledad y a la desilusión. La misma agua, paradójicamente, le of rendaba el consuelo de una integración narcisista, único acto amatorio posible. La carencia de agua le insta a volver imaginativamente al agua abundante que "aceptaba el beso de [su] belfo", y al tentativo amor de Ariana, que se confesó "sedienta de [sus] belfos rumorosos" (51). Rota la fantasía, el Minotauro se da cuenta de que el hilo no lo conduce físicamente a ningún lugar - sólo alienta su memoria e imaginación, los únicos aspectos libres de su ser. Se resigna a rechazar el hilo-ombligo, aparte de la sospecha de que Ariana haya pactado contra él, para quedarse donde su propia 
imagen permanezca intacta: "A solas soy un ser de armonioso trazado" (61). Su sensibilidad le intima que vivía hostigado por su excentricidad corpórea, pero "Aquí, dice, era especie e individuo, cesaba mi monstruosa discrepancia". Rehusa el pasado (palacio) y el futuro (palacio), sitios y tiempos de desolación, y opta por el eterno "ahora": "Ahora veo solamente el laberinto, otra vez solamente el laberinto" (60).

Teseo aspiraba constantemente a la suprema fuerza que subyugara 2 los demás a su voluntad, $y$ ahora busca acabar de una vez con el cuerpo del Minotauro creyendo que este acto mortífero terminaria la historia fabulosa que divinizaba al Minotauro. Los maestros sabios de Teseo ("retóricos") alentaban sus celos, pero éste ha aprendido a cultivar los celos despersonalizados v.g., a disociar el sentimiento de sus actos homicidas y besticidas: "No te mato a ti sino a tus actos, al eco de tus actos, su resonar lejano en las costas griegas" (57). El Minotauro responde análogamente - "Aquí no llega el rumorear de los puertos" (58) - consciente del múltiple significado. Infiere, por su parte, que la vanagloria $\mathrm{y}$ el heroísmo ajenos no to afectan. En sentido inverso que desmiente su respuesta, el alcance de su propia fama le es cono. cido a través del temor de Minos y de las víctimas. Teseo intentará destruirlo física y espiritualmente en una acción impersonal que separa hecho y pensamiento con el fin de utilizar el mito de Teseo, basado en la fuerza, para deshacer otro mito, el del Minotauro.

La anfibología (toro-hombre), oscuridad-sol, agua-sequía, compañíasoledad, héroe-cobarde) que angustia al Minotauro parece desvanecerse ante la respuesta de Teseo a la siguiente pregunta: "Si te of rezco el cuello, ¿seré cobarde?" (62). El Minotauro se suaviza ahora, pierde su rencor: "No hay malicia en tus ojos, joven rey" (63). En un acto sorpresivo, el Minotauro descarta la tradición de combate físico, tan querido de los Teseos, y abre camino a que la palabra, la suya propia, decida su destino. En su afán de eliminar la mayor anfibología, progenitora de todas - vida-muerte- se rinde voluntariamente: " $\mathrm{No}$ comprendes que estoy pidiendo que me mates, que estoy pidiendo la vida?"21 (65). Al abandonar la vida para alcanzar la inmortalidad, el pagano Minotauro se anticipa al prototipo del cristiano sacrificado. Su acto no es, como entre los cristianos; gratuito, desinteresado, porque lo impulsa el sentimiento de que, muerto, llegue a la máxima integración personal ("Muerto seré más yo": [63]) y se vengue de Teseo. El Minotauro no se defiende instintivamente del ataque mortal, como una bestia, porque no lo es

21 Esta frase, que emplea oxímoron, linda en lenguaje místico. El Minotauro busca la herida que confiere el amor $y$ la vida eternos. 
esencialmente, a diferencia de los que se visten de hombres y son asesinos por completo. Combate con la inteligencia por la inteligencia. Ia conquista, para él, consiste precisamente en trascender su condición física de bestia, la de Teseo, en negar su humanidad para conservar el instinto bestial.

Arguye el Minotauro que Teseo busca y consigue lo efímero al matarlo, para luego escaparse y vanagloriarse del poder político y de la posesión de Ariana. Si los Teseos - materialistas y oportunistas- han de poblar la tierra no evitarán, por eso, la penetración del ubicuo Minotauro en los sueños "de sus hijos" desde donde minará su propia fuerza política ("... cornearé tu trono") y su papel de héroe $\mathrm{y}$ de rey. ${ }^{22} \mathrm{La}$ apoteosis se realizará, también, por una intromisión incestuosa en el sueño de Ariana, lo cual de veras espanta a Teseo más que la muerte misma:

Ariana, en tu profundidad inviolada

iré surgiendo como un delfín azulísimo.

Como la ráfaga libre que soñabas vanamente.

¡Yo soy tu esperanza!

¡Tú volverás a mí porque estaré instaurado, incitante $y$ urgido,

en tu desconcertante doncellez de sueño! ${ }^{23}$ (67).

Teseo está forzado a publicar la muerte para exorcizar estas palabras lúbricas y proféticas que zumban en sus oídos y calan al hueso: "¡Calla! ¡Muere al menos callado!... ¡Los héroes odian las palabras!" (68). Con gritos y muertes cree poder evitar la visión apocalíptica del Minotauro, de que "la tierra de los hombres guarde mi argumento en el secreto río de la sangre" (64).

\section{Acto v}

A través del Citarista, que tañe para el agonizante Minotauro, se descubre que la tortura y la muerte no fueron el destino de los que, asustadizos, entraron como parte del rito del sacrificio a pagar la deuda

22 Los temores de Minos (" Como si afilara su doble rayo contra el mármol!" [18].), están relacionados con la profecía del Minotauro a Teseo "Cuernos de mármol se afilarán un día contra tu pecho" [63].). Se completa el círculo de Möbius guardando asimismo la continuidad y la simetría lingüísticas.

${ }_{23} \mathrm{La}$ tradición gongorina se evidencia aqui, como en otros trozos, por el desplazamiento de adjetivos, el uso de colores y luces que intensifican la sensualidad, y cierta opacidad de comprensión, debido, no a imágenes clásicas, sino a la magia de una simbología tétrica. Arreglo la frase como un poema para destacar su intensidad. 
del asesinato de Androgeo, el hijo de Minos. Se aclara, pues, el enigma del laberinto, de que no es cárcel, sino templo, donde los atenienses se dedican a tendir culto a la figura escindida que les otorga la integridad. Al principio, aprendieron a deshacerse del miedo que provino de su ignorancia pública y su soledad esencial. Iuego descartaron las formas externas y tradicionales del amor, de la belleza y de la felicidad. $\mathrm{Y}$, finalmente, renovaron su fe individual $\mathrm{y}$ colectiva ante una nueva deidad, que en la vida previa y ultralaberíntica era símbolo de lo grotesco pero que en su propio sitio es una figura de armoniosa traza: "Mira, sólo hay un medio para matar los monstruos: aceptarlos" (64). El Minotauro alienta al entristecido Citarista a que siga tañendo y a que Nydia baile, sabiendo que el mayor goce no consiste en la expresión de formas externas de la felicidad.

Los fieles prometen no olvidarlo, aunque el Minotauro rechaza "el recuerdo [humano como] hábito insensato de la carne" (74). Jura arraigarse en el ser de los atenienses, y así perpetuarse de una manera permanente: "En una hora alta acudiré a tu voz, y lo sabrás como la luz que ciega, cuando el Músico diga en ti los números finales" (75). Les ofrece una verdadera liberación, y no un simple rescate del cuerpo físico, tal como lo hizo Teseo. Tanto en la vida como en la muerte los atenienses han de guiarse por el amor y la compasión, artículos de fe aprendidos junto al Minotauro, y de este modo evadirán la verdadera muerte que es la extinción del alma, ejemplificado en las palabras clave del Minotauro a Teseo: "¿Qué sabes tú de muerte, dador de la vida profunda?" (64). En este duelo de Eros (amor-plenitud-vida) contra Thanatos (odio-destrucción-muerte), ${ }^{24}$ se ilumina el contraste esencial entre el Minotauro, que opta por el centro laberíntico para integrar su ser por medio del amor, aunque lo lleve a la muerte física, y Teseo, el que persigue la linealidad del mundo material donde se dedica al afán de manipular, dividir, y conquistar.

Cortázar arrebata, entonces, la larga tradición que se asocia con un idealizado Teseo, destructor de monstruos y redentor de pueblos, transformándolo en un opresor vulgar que, guiado por el instinto, mata vidas e ilusiones. El Minotauro, en contraste, ya no es el símbolo del hombrebestia que persigue la gratificación sexual. ${ }^{25}$ Pierde su condición grotesca

24 El concepto Eros contra Thanatos se deriva de' las ideas de Carl Gustav Jung. Guardo para otra ocasión un estudio que enlaza a Cortázar con Jung, Schopenhauer y Nietzsche.

${ }_{25}$ La transformación del Minotauro se nota en los dibujos de Picasso para una nueva edición (1931) de Albert Skira de las Metamorphoses de Ovidio. Picasso, junto con André Dérain, Joao Miró, René Magritte, Max Ernst y Diego 
y se reviste del ideal de la Grecia Antigua - la armonía del ser. Libertado del impulso de emplear la fuerza física, conquista con la palabra sabia, la ternura repartida, la muerte voluntaria, y la profecia de inquietar los sueños de los reyes, enemigos del alma.

University of California, Berkeley.

Martín C. TAYlor 